\title{
Enterotoxigenic and nontoxigenic Bacteroides fragilis strains isolated in Brazil
}

\author{
Karla R Miranda $/{ }^{+}$, Mariana F Dias, Priscilla LS Guimarães, Renata F Boente, Heidi Pauer, \\ Priscila Z Ramos, Laís S Falcão, Eliane de O Ferreira, Ilana T Balassiano/', Livia Q Ferreira, \\ Joaquim dos Santos-Filho, Geraldo R de Paula², Eduardo NF Antunes ${ }^{1}$, Katia ES Avelar', \\ Regina MCP Domingues
}

\begin{abstract}
Laboratório de Biologia de Anaeróbios, Departamento de Microbiologia Médica, Instituto de Microbiologia Prof. Paulo de Góes, Universidade Federal do Rio de Janeiro, Av. Carlos Chagas Filho 3737, 21941-900 Rio de Janeiro, RJ, Brasil 'Laboratório de Zoonoses Bacterianas, Instituto Oswaldo Cruz-Fiocruz, Rio de Janeiro, RJ, Brasil ${ }^{2}$ Departamento de Tecnologia Farmacêutica, Faculdade de Farmácia, Universidade Federal Fluminense, Niterói, RJ, Brasil
\end{abstract}

The presence of enterotoxigenic Bacteroides fragilis and nontoxigenic B. fragilis (NTBF) among 109 strains isolated from 1980-2008 in Brazil were investigated by PCR. One strain, representing 0.9\% of the total analyzed strains, harbored the bft gene which was identified as bft-1 isoform based on PCR-RFLP and sequencing. Fortynine strains (44.9\%) exhibited the NTBF pattern III which possesses the flanking region required for pathogenicity island acquisition in which the bft gene is codified. These data reinforce the potential of $\mathrm{B}$. fragilis as an emerging enteropathogen in our country.

Key words: Bacteroides fragilis toxin - enterotoxigenic Bacteroides fragilis - nontoxigenic Bacteroides fragilis

Bacteroides fragilis is a Gram-negative obligate anaerobic bacterium and constitutes about $1 \%$ of the normal faecal flora of humans (Drasar \& Duerden 1991). The bacterium is usually isolated from endogenous infections (Eribe \& Olsen 2000) and its pathogenicity has been attributed to several virulence determinants, including an enterotoxin encoded by the $b f t$ gene (Sears et al. 2006). According to the presence of a $B$. fragilis Pathogenicity Island (BfPAI) and its flanking region, $B$. fragilis strains can be classified mainly in: (1) enterotoxigenic $B$. fragilis (ETBF) strains, or pattern I, containing BfPAI and its flanking region within the conjugative transposon CTn86 ( $\sim 65 \mathrm{~kb})$; (2) nontoxigenic B. fragilis (NTBF) strains, or pattern II, lacking the BfPAI as well as a flanking CTn; and (3) NTBF strains, or pattern III, that lack the BfPAI but contain conjugative transposons, either CTn9343 or variants of CTn9343 or CTn86 (Moncrief et al. 1995, Franco et al. 1999, Franco 2004, Buckwold et al. 2007). The detection of the $b f t$ gene in a BfPAI embedded in a $\mathrm{CTn}$ suggests that the toxin gene can be passed by horizontal gene transfer events from ETBF strains to NTBF strains of pattern III (Moncrief et al. 1995).

In order to follow the evolution of enterovirulence profiles in Brazil, we determined in the present study the distribution of ETBF and NTBF patterns in $109 \mathrm{~B}$. fragilis strains obtained between 1980-2008 from several hospitals in Rio de Janeiro. All strains were cultivated

Financial support: Faperj, CNPq, MCT/PRONEX/Faperj

+ Corresponding author: karlarodr@yahoo.com.br

Received 15 May 2008

Accepted 26 September 2008 anaerobically following recommendations of JousimiesSommer et al. (2002). B. fragilis ATCC 43859 and ATCC 23745 strains, respectively, were used as positive and negative controls for $b f t$ gene detection by PCR.

Extraction and purification of DNA were performed according to Pitcher et al. (1989). Amplification conditions were the same as reported by Scotto d'Abusco et al. (2000). Primers BF-5 (5' -GATGCT CCAGTTACAGCTTCCATTG-3') and BF-6 (5' -CGCCCAGTATATGACCTAGTTCGTG-3') were used to amplify a 976-bp internal fragment of the three isoforms of the $b f t$ gene (pattern I) (Scotto d'Abusco et al. 2000). A fragment of expected size was amplified from one $B$. fragilis strain $(0.9 \%)$ which was classified as ETBF. Other studies in Brazil already reported low numbers of ETBF strains, ranging from 1.5-3.0\% (Bressane et al. 2001, Antunes et al. 2002, Krzyzanowsky \& Avila-Campos 2003). Nevertheless, high numbers of ETBF strains have been isolated in several other regions of the world (Kato et al. 1996, Pantosti et al. 1997). For instance, ETBF represented $18.6 \%$ of the strains isolated in Japan (Kato et al. 1996) while in Poland and in Netherlands rates of approximately $14 \%$ were found (Obuch-Woszczatyński et al. 2004).

For amplification reactions of the $12-\mathrm{kb}$ regions flanking BfPAI, we used primers P1T3 (5' - TTCAACCTGATCGATCCGGAAGATCCG- 3') and PIT7 (5' GGTAGACTACCTGAGTAAGGAGTC-3'), that yield a $1.6 \mathrm{~kb}$ fragment in NTBF pattern III strains (Scotto d'Abusco et al. 2000). A 1.6kb fragment was amplified from 49 strains $(44.9 \%)$. NTBF III was the most frequent pattern and was present in $40.8-55.5 \%$ of the samples (Table).

By using PCR restriction fragment length polymorphism to classify bft isoforms (Scotto d'Abusco et al. 2000), the ETBF strain isolated was shown to harbor the $b f t-1$ isoform (data not shown). Moreover, the amplified 
TABLE

Distribution of Bacteroides fragilis patterns between the 109 strains isolated in Brazil from 1980-2008

\begin{tabular}{lcccccc}
\hline & \multicolumn{2}{c}{$1980-1989$} & \multicolumn{2}{c}{$1990-1999$} & \multicolumn{2}{c}{$2000-2008$} \\
\cline { 2 - 7 } & $\mathrm{n}$ & $\%$ & $\mathrm{n}$ & $\%$ & $\mathrm{n}$ & $\%$ \\
\hline ETBF & 0 & 0 & 0 & 0 & 1 & 2.3 \\
NTBF III & 10 & 55.5 & 20 & 40.8 & 19 & 45.2 \\
Total $^{a}$ & 18 & 100 & 49 & 100 & 42 & 100 \\
\hline
\end{tabular}

$a$ : total of strains analyzed per period; ETBF: enterotoxigenic Bacteroides fragilis; n: number of positive strains; NTBF: nontoxigenic Bacteroides fragilis.

bft gene fragment was purified (Illustra GFX ${ }^{\mathrm{TM}} \mathrm{PCR}$ DNA and Gel Band Purification Kit, GE Healthcare) and sequenced at the Human Genome Research Center (Institute of Biosciences, University of São Paulo) by using the MegaBACE ${ }^{\mathrm{TM}} 1000$ and DYEnamic ET Dye Terminator Cycle Sequencing Kit (Thermo Sequenase ${ }^{\mathrm{TM}}$ II DNA Polymerase). The sequence was edited with the BioEdit Sequence Alignment Editor version 7.0.1 and analyzed by Blast software (www.ncbi.nlm.nih.gov/blast) against sequences deposited in GenBank. The nucleotide sequence of the bft gene showed $99.9 \%$ similarity with the deposited $b f t-1$ sequence. This result is in agreement with several similar studies where the $b f t-1$ allele was found to be the most predominant isotype (Moncrief et al. 1995, Ulger et al. 2006, Avila-Campos et al. 2007).

In summary, only one single ETBF strain was identified among 109 Brazilian samples used in this study. This result is in agreement with several other reports that demonstrated a low incidence of ETBF in our country. Based on the percentage of NTBF III detected and assuming a possible horizontal transfer, further investigations are required to monitor eventual changes in the enterovirulence pattern of this microorganism.

\section{ACKNOWLEDGEMENTS}

To Dr. Walter Oelemann, for his assistance.

\section{REFERENCES}

Antunes ENF, Ferreira EO, Vallim DC, Paula GR, Seldin L, Sabrá A, Ferreira MCS, Domingues RMCP 2002. Pattern III non-toxigenic Bacteroides fragilis (NTBF) strains in Brazil. Anaerobe 8: $17-22$

Avila-Campos MJ, Liu C, Song Y, Rowlinson M-C, Finegold SM 2007. Determination of $b f t$ gene subtypes in Bacteroides fragilis clinical isolates. J Clin Microbiol 45: 1336-1338.

Bressane MA, Durigon LE, Avila-Campos MJ 2001. Prevalence of the Bacteroides fragilis group and enterotoxigenic Bacteroides fragilis in immunodeficient children. Pathogenesis 7: 277-281.
Buckwold SL, Shoemaker NB, Sears CL, Franco A 2007. Identification and characterization of conjugative transposes $\mathrm{C} T \mathrm{n} 86$ and CTn9343 in Bacteroides fragilis strains. Appl Environ Microbiol 73: 53-63.

Drasar BS, Duerden BI 1991. Anaerobes in the normal flora of man. In BI Duerden, BS Drasar, Anaerobes in Human Disease, Wiley-Liss, New York, p. 162-179.

Eribe ER, Olsen I 2000. Strain differentiation in Bacteroides fragilis by ribotyping and computer-assisted gel analysis. APMIS 108 : 429-438.

Franco AA 2004. The Bacteroides fragilis pathogenicity island is contained in a putative novel conjugative transposon. J Bacteriol 186: 6077-6092.

Franco AA, Cheng RK, Chung G-T, Wu S, Oh H-B, Sears CL 1999. Molecular evolution of the pathogenicity island of enterotoxigenic Bacteroides fragilis strains. J Bacteriol 183: 6623-6633.

Jousimies-Sommer HR, Summanen P, Citron DM, Baron EJ, Wexler HM, Finegold SM 2002. Wadsworth-KTL Anaerobic Bacteriology Manual, 6th ed., Star Publishing, Belmont, 287 pp.

Kato N, Kato H, Watanabe K, Ueno K 1996. Association of enterotoxigenic Bacteroides fragilis with bacteremia. Clin Infect Dis 23 (Suppl. I): 83-86.

Krzyzanowsky F, Avila-Campos MJ 2003. Detection of non-enterotoxigenic and enterotoxigenic Bacteroides fragilis in stool samples from children in São Paulo, Brazil. Rev Inst Med Trop São Paulo 45: 225-227.

Moncrief JS, Obiso R, Barroso LA, Kling JJ, Wright RL, Van Tassell RL, Lyerly DM, Wilkins TD 1995. The enterotoxin of Bacteroides fragilis is a metalloprotease. Infect Immun 63: 175-181.

Obuch-Woszczatyński P, Wintermans RG, Van Belkum A, Endtz H, Pituch H, Kreft D, Meisel-Mikołajczyk F, Luczak M 2004. Enterotoxigenic Bacteroides fragilis (ETBF) strains isolated in The Netherlands and Poland are genetically diverse. Pol J Microbiol 53: 35-39.

Pantosti A, Menozzi MG, Frate A, Sanfilippo L, D’Ambrosio F, Malpeli M 1997. Detection of enterotoxigenic Bacteroides fragilis and its toxin in stool samples from adults and children in Italy. Clin Infect Dis 24: 12-16.

Pitcher DG, Saunders NA, Owen RJ 1989. Rapid extraction of bacterial genomic DNA with guanidine thiocyanate. Lett Appl Microbiol 8: 151-156.

Scotto d'Abusco A, Grosso MD, Censini S, Covacci A, Pantosti A 2000. The alleles of the $b f t$ gene are distributed differently among Enterotoxigenic Bacteroides fragilis strains from human sources and can be present in double copies. J Clin Microbiol 38: 607-610.

Sears CL, Buckwold SL, Shin JW, Franco AA 2006. The C-terminal region of Bacteroides fragilis toxin is essential to its biological activity. Infect Immun 74: 5595-5601.

Ulger Toprac N, Rajendram D, Yagci A, Gharbia S, Shah HN, Gulluoglu BM, Akin LM, Demirkalem P, Celenk T, Soyletir G 2006. The distribution of the $b f t$ alleles among enterotoxigenic Bacteroides fragilis strains from stool specimens and extraintestinal sites. Anaerobe 12: 71-74. 